The Future of Online Learning

\title{
The Future of Online Learning: An Outlook Based on Recent Worldwide Pandemic
}

\section{Experience}

\author{
N. Ravichandran ${ }^{1}$, Chhavi Kohli ${ }^{2}$ \\ ${ }^{1}$ Professor (Retired), Indian Institute of Management Ahmedabad, India \\ ${ }^{2}$ Former Academic Associate, Indian Institute of Management Ahmedabad, India
}

\begin{abstract}
The COVID 19 pandemic has shaken the world with rising deleterious effects. It triggered some fundamental changes to several population segments sand multiple sectors of the economy. The education system is no exception. With the educational institutions being closed due to lockdown for extended duration, delivery of education has been impacted. This paper examines the impact of COVID-19 pandemic on education services and proposes an outlook regarding the future of online learning. Given the acceptance by participants (learners and teachers) and advantages (in terms of spread and volume) of online learning over traditional learning, the online learning would continue to exist.
\end{abstract}

Keywords: impact of COVID-19, effectiveness of online learning, brick-and- mortar universities

\section{Author Note}

N Ravichandran (Dhttps://orcid.org/0000-0002-2839-1096

Chhavi Kohli Dhttps://orcid.org/0000-0002-8395-9844

We have no known conflict of interest to disclose.

Correspondence concerning this article should be addressed to: Chhavi Kohli, B6-43, Goyal Intercity, Bodakdev, Ahmedabad - 380 054, India. Email: chhavi.manra@gmail.com 


\section{The Future of Online Learning: An Outlook Based on Recent Worldwide Pandemic}

\section{Experience}

COVID-19 Pandemic brought the entire world to a pause. It made governments and institutions to re-strategize the future without compromising on health-related safety concerns of individuals. The spread of the virus has challenged everyone in unique and unexpected ways. This situation compelled various businesses to look for and adopt survival methods rapidly. Closure of educational institutions in response to the pandemic, significantly altered the traditional education practices and created an opportunity for online learning. Change is easily adopted when there is no alternative. Though online learning existed even before the COVID-19 pandemic, it gained prominence as a consequence of the pandemic.

This paper is organized into 4 sections. Section 1 presents the COVID-19 situation in India and its impact on various segments of the population and sectors of the economy. A brief discussion on the impact of the pandemic on the education sector concludes this section. Section 2 reviews the published literature on the impact of COVID-19 in general and with specific reference to the education systems. Section 3 is focused on recent developments in online education. It outlines various online learning initiatives across different educational (primary, secondary, and tertiary) segments. The final, Section 4, presents an outlook on the future of online learning and its unintended consequences to the Education Ecosystem.

\section{The Covid Situation in India: Highlights}

The outbreak of coronavirus caused a pandemic that has put the world in jeopardy and changed the global outlook massively. The COVID -19 pandemic has made more than 200 million people worldwide sick.

As of September 24, 2021, "There have been 230,418,451 confirmed cases of COVID-19, including 4,724,876 deaths. ("WHO Coronavirus (COVID-19) Dashboard," 
n.d.). China faced a COVID outbreak in December 2019. By late January, many countries across the globe started witnessing this new mysterious disease.

India witnessed its first COVID-19 case in late January 2020 when three Indian students travelled to the southern state of Kerala from Wuhan in China- the epicentre of the outbreak. At the same time, a few other cases were reported in other parts of the country, most of which were linked to people with a travel history to affected countries. Infections rose rapidly beginning in March 2020" (Statista, 2021). In order to contain the spread, a nationwide lockdown was imposed in four phases during $25^{\text {th }}$ March to $31^{\text {st }}$ May 2020.

From June 2020 onwards, the lockdown was gradually lifted. At that time, India was reported as the fifth worst-hit nation across the world. "With lockdown being lifted over the latter half of 2020, the economy was able to bounce back to some extent ("COVID-19: Another reason why unlock 1.0 may be ill-timed in India," 2020). The negligence in social and personal behaviour after Unlock 2.0 led to a gradual increase in the number of infections. "India was observed to have the fastest infection rate worldwide in August 2020. Daily cases peaked in September with 90,000 cases" (John and Seshadri, 2020).

Meanwhile, Phase-1 clinical trials of India's first indigenous COVID-19 vaccine, Covaxin, began across the country. Eventually, India commenced its vaccination programme on $16^{\text {th }}$ Jan 2021. After a couple of months of vaccine availability and implementation, the second wave of the pandemic occurred. India reported record numbers for daily infections and deaths for nearly two weeks in April 2021. "Over 4 lakhs cases were reported in a single day during second wave. Sudden surge in cases caused imposition of curfew and lockdown in several states. India's health infrastructure was stretched due to explosive demand for oxygen and antiviral drug like Remdesivir etc. Shortage of hospital beds and oxygen ventilators was reported. Health care and frontline workers experienced excessive work-related emotional stress. Situation went unmanageable to a great extent during that time" (Kumar, 2021). 
"The launch of mass inoculation programme in first phase covered an estimated 30 million healthcare and front-line workers. Second phase was initiated in March to cater to population with co-morbidities and the cohort of above 60 years of age. After a month, it was extended for everyone above 45 years of age. Public response for vaccination was not very enthusiastic initially subsequently, overcrowding and shortage of doses was reported due to mismatch in demand and supply of doses. Rise in cases contributed towards sudden increase in demand for vaccines which eventually led to a chaos at vaccination centres" (Rakesh et al., 2021). By October of 2021 around 17.3\% of the Indian population was fully vaccinated and more than $48.0 \%$ had received at least one dose (Coronavirus in India: Latest Map and Case Count, 2021).

Some vital statistics relating to the pandemic are shown in Figures 1-2.

\section{Figure 1}

Infections, Recoveries and Deaths

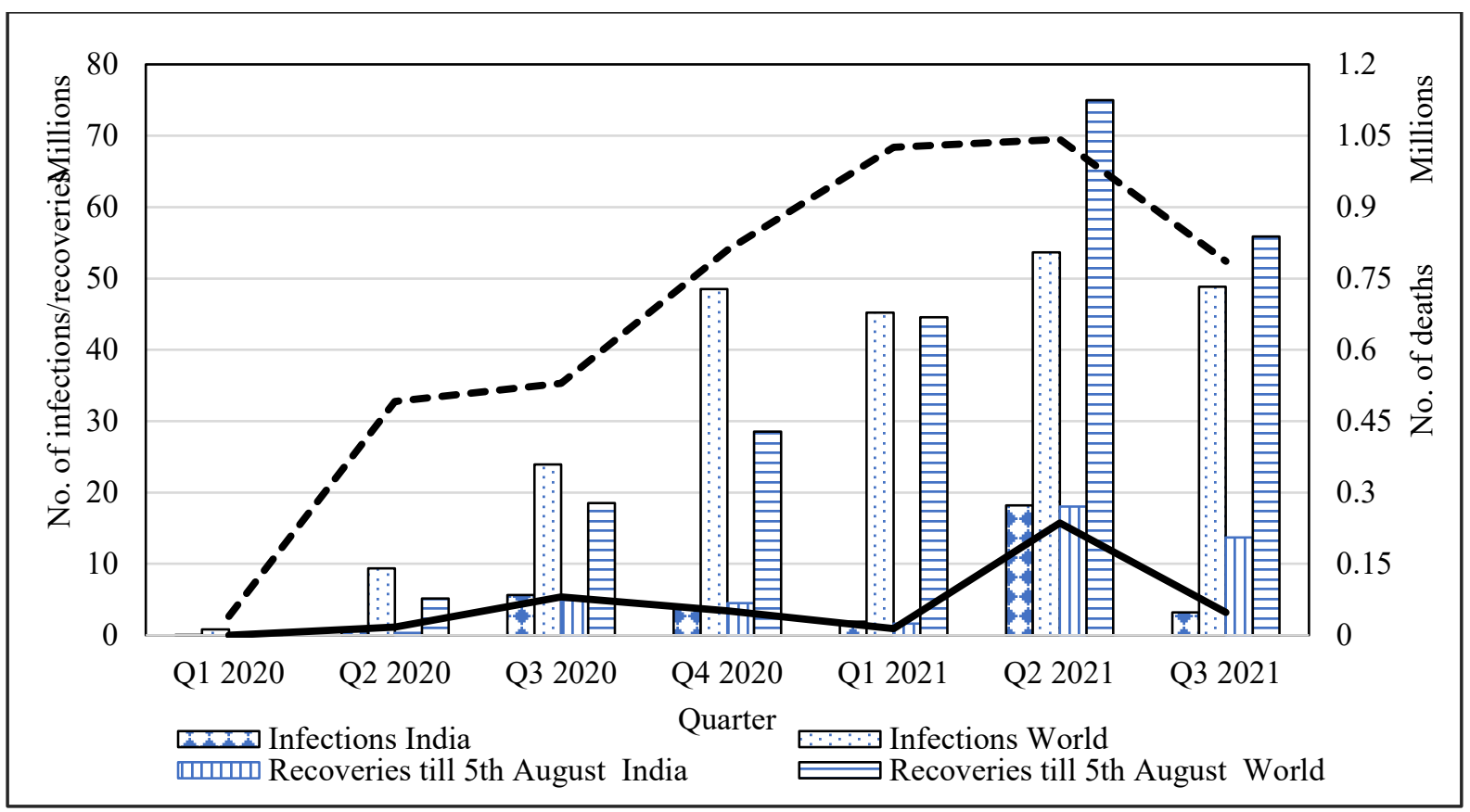

Source "WHO Coronavirus (COVID-19) Dashboard," (n.d.) 


\section{Figure 2}

Testing and Positivity Rate

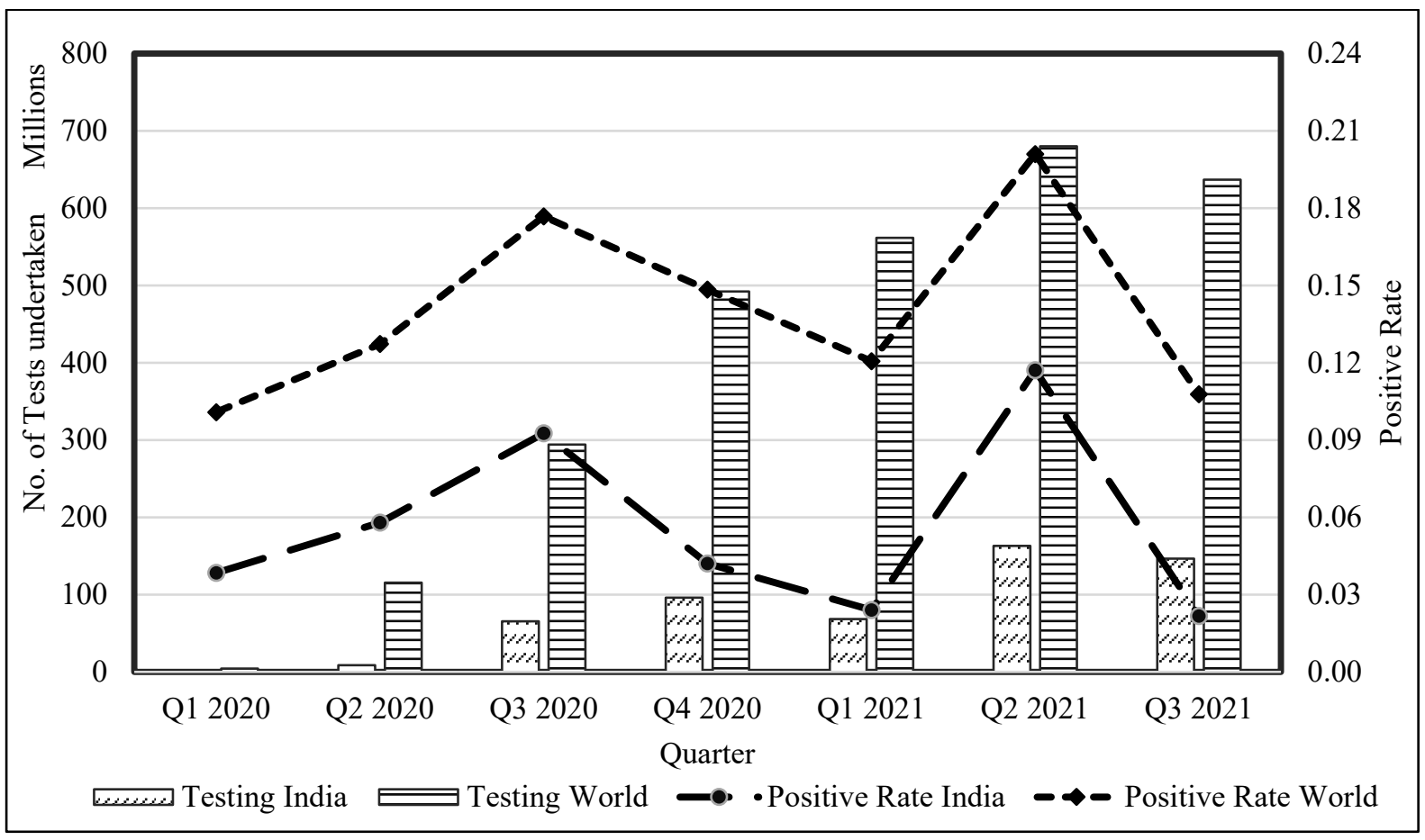

Source: "Novel coronavirus (COVID-19) cases data," (2020)

\section{General Impact of the COVID-19 Pandemic}

The COVID-19 pandemic has significantly impacted various population segments and various sectors of the economy. The Indian government imposed several measures such as lockdown, social distancing norms, etc., to contain the spread of the virus. These measures restricted the movement and mobility of individuals and consequently economically impacted the daily lives of many people.

During the early days of lockdown there was an atmosphere of confusion among people. Lack of clarity as what to do and what not to do, and uncertainty regarding the health hazards arising out of the pandemic characterised the situation. Hence, many people resorted to panic buying and stockpiling essential household items. This resulted in long queues in daily essential shops such as grocery stores, medical shops, etc. Due to the inconvenience 
experienced during shopping, consequent to lockdown restrictions and overcrowding, a shift towards online purchase was noticed in urban areas.

Older people and those with underlying health conditions have been at significant risk of developing severe illness in the case of contracting the COVID-19 virus. Thus, they have been one of the worst hit segments both by the virus and by lockdown-induced anxiety. They benefited least from digital solutions. "About $88 \%$ of all COVID-19 deaths took place in the age group of 45 years and above making them a vulnerable group" (“88\% of all”, 2021).

"The impact of crises is never gender-neutral and Covid-19 is no exception" (UN Women, 2020). Women of every socioeconomic background faced various sets of challenges. There have been job losses, increased domestic work burdens, tension and stress arising from family member(s) working from home. Also, women from poor economic strata have been facing even higher risks of COVID-19 transmission, loss of livelihood, and increased domestic violence.

Although children have been largely spared the direct mortality impacts of COVID19, their lives changed in many ways. Suspending school services affected all school-going children, impacting their routine behaviours and the learning process severely. Children from under-privileged backgrounds with no access to internet have been particularly impacted, to the extent of dropping out of the learning process.

The lockdown shut down factories and work places, which led to job losses and shortage of food for families of blue collar workers. There were job losses among the whitecollar workforce as well. Thus, within a month of lockdown, the unemployment rate in India increased from $8.7 \%$ to $23.52 \%$. Further, the sudden announcement of lockdown made Indian migrant workers vulnerable. Millions were stranded in various parts of the country away from home. They faced multiple hardships: economic, emotional, and social. As there were no transport, many walked back home. 
Furthermore, with the rising number of infections, health care workers and frontline workers were strained. Doctors, nurses, and paramedics have been braving grave odds each day in order to support the functioning of the health care system. Members of law enforcement agencies took a lot of risks in order to supervise and facilitate strict observance of lockdown guidelines. Overall, there has been no segment of the population which remained untouched by this pandemic.

The enormity of the lockdown also affected the economy. It put an immediate halt to many business operations across the nation. A slowdown was observed in labour-intensive sectors such as manufacturing, construction, real estate, etc. Due to lockdown-imposed restrictions, logistics of goods was impacted and this in turn impacted many other sectors dependant on it. Mass transportation (both intracity and intercity) was stressed. Many public transports and rental services companies suspended their services due to lockdown.

Coronavirus disruption also led to innovations in various sectors. For example, the pharma world evolved with the adoption of digitisation practices. There has been a significant surge in e-commerce. Also, banking and education services that do not require direct contact and delivered remotely were restored quickly. To sum up, the sectors where there is no physical activity or interaction with customer revived faster.

\section{Impact of the COVID-19 Pandemic on Education}

"Education has been impacted by COVID-19 pandemic by pushing 1.53 billion students out of school. Pandemic affected $87.6 \%$ of the world's total enrolled learners." ("COVID-19 and education in emergencies," 2020)(COVID-19 AND EDUCATION IN

\section{EMERGENCIES - Educationcannotwait, n.d.)}

In the Indian context the impact has been challenging and transformational. With schools and colleges being closed down due to the nationwide lockdown, education delivery and the learning process suffered. Students were not allowed to go to school. Both school and 
college examinations were postponed for an indefinite period of time. Mass promotion was approved. Competitive exams for the selection of professionals in various segments was postponed.

The education system went through a massive transformation from a physical infrastructure-based system to an online system. The online mode of education helped in building digital skills too. There has been a significant surge in the usage of technology (i.e., virtual tutoring, video conferencing tools, and software) in education. Various online educational initiatives like online classrooms, webinars, digital exams, and so on have been introduced. But the ground realities are glaring at the presumption of the paradigm shift that a digital platform has triggered. Many kids did not have access to remote learning prerequisites. According to the Global internet network research, just 24\% of households had a consistent internet connection, while other remote geographical areas remained unreachable.

The effectiveness of online education is open to debate. E-education calls for infrastructure overhaul, access to high-speed internet, and interactive sessions training. Noncompliance with such prerequisites rendered e-classes ineffective. The interactive sessions malfunctioned sometimes, leaving students confounded and teachers frustrated. But the reality is that this is the new normal. The main participants (educational institutions and learners) adopted this way of life over time

\section{E-Learning Experiences}

Even before Covid, there were many e-learning initiatives. COVID-19 has given an impetus to all of them. The Dr. K. R. Shroff Foundation is working towards improving the quality of life of many remote communities by educating their school students and providing modern learning methods and equipment to the underprivileged. As far as e-learning is concerned, this Foundation has partnered with several agencies to create animated academic 
video content from $3^{\text {rd }}$ standard onwards, in Gujarati, for students to watch and learn. The Foundation is also engaged in bridge courses for students with weak educational backgrounds. They provide students with the fundamental knowledge of all subjects using interactive multimedia content. Also, the foundation partnered with various organisations to train teachers and support various schools in remote areas.(https://www.krsf.in/best-of-thefoundation-in-gujarat/).

BYJU'S is an ed-tech company and the creator of a popular school learning app. It was launched in 2015. It offers personalised online learning programs for classes 1- 12 (K12). Fifty million students have registered with BYJU'S and 3.5 million have paid subscriptions. The courses offered include Maths, Physics, Chemistry, and Biology for CBSE and ICSE (Classes 1-12). The learning app brings together teachers, technology, content, and media for creating a seamless learning experience for every student.(https://byjus.com/)

Khan Academy is an American non-profit educational organization created in 2008 by Sal Khan. The goal of Khan academy is to create a set of online tools that help students to learn. The academy produces short lessons in the form of videos. Their website includes supplementary practice exercises and materials for educators. It is free and accessible for learners and teachers (https://www.khanacademy.org/about)

Great Lakes E-Learning (https://www.greatlakes.edu.in/e-learning-programs/) offers online and blended programs for working professionals who seek to develop their analytical skills. They provide courses in various domains such as analytics and data science, artificial intelligence, management, and cloud computing for fresh graduates and early career professionals as well. These online and blended learning programs for working professionals are offered in collaboration with Great Learning, a leading technology enabled online and blended learning platform. Mohan Lakhamraju and Hari Nair founded Great Learning in the 
year 2013 to realize their dream of making every working professional data proficient. . (https://www.greatlakes.edu.in/e-learning-programs/).

Coursera Inc. is a massive American open and online course provider founded in 2012 by Stanford University computer science Professors Andrew Ng and Daphne Koller. Coursera works with universities and other organizations to offer online courses, certifications, and degrees in a variety of subjects. Their products include Master Track Certificates courses, Bachelor's and Master's degree courses, professional certificate programs, specialisation courses, free courses, and guided projects. Coursera partners with more than 200 universities and companies to bring flexible, affordable, and job-relevant online learning to individuals and organizations worldwide. Coursera works with global partners across 140 countries to provide free education to tens of thousands of refugees Harvard Online Edx is a platform created by Harvard University. As a research university and non-profit institution, Harvard is devoted to excellence in teaching, learning, and research, and to developing leaders in many disciplines. It offers countless non-degree opportunities for professional and lifelong learners, including executive education, continuing education, and online courses. Harvard's Edx platform provides a variety of free and paid online courses. Many courses are available to audit for free, or for a fee for certification purposes. More than 250 courses are available in a wide range of subjects such as Art \& Design, Business, Computer Science, Data Science, Humanities, Mathematics, Education and Teaching, Health and Medicine, etc. ("Transformation," n.d.).

Some government funded initiatives have been contributing to virtual education. NPTEL - MOOC: The National Programme on Technology Enhanced Learning (NPTEL) was initiated by seven Indian Institutes of Technology (Bombay, Delhi, Kanpur, Kharagpur, Madras, Guwahati, and Roorkee) along with the Indian Institute of Science, Bangalore, in 2003. It is part of a project funded by MHRD, Govt. of India. It has created web and video 
courses in all major branches of engineering and physical sciences at the undergraduate and postgraduate levels and management courses at the postgraduate level. It provides a large online repository of the courses in engineering, basic sciences, humanities, and social sciences subjects. NPTEL has a YouTube channel as well. NPTEL provides video content. They offering open online courses in March 2014. For those who completed the courses successfully, certificates were awarded by IITs. Joining a course is free while certification is charged . Learning can be done by watching videos. Learning proficiency is tested by weekly assignments to be submitted online within the prescribed deadlines. The provision of discussion forums for the doubts and queries of learners enhances the learning experience ("Nptel, online courses and certification, Learn for free," n.d.).

Courses are offered with consideration for students in non-urban and rural areas through supplementary DVDs and mobile delivered content. The faculty who offer courses are from the IITs or from other reputed institutes such as CMI, IMSc, etc. To take this initiative forward and to encourage more students across colleges to participate in this initiative, NPTEL set up local chapters in partnership with colleges named as SWAYAMNPTEL. NPTEL partners with 4200+ colleges (as of now) in the form of NPTEL local chapters.

SWAYAM MOOCs platform is an online free e-learning platform portal designed for covering school/vocational, undergraduate, postgraduate, engineering and other professional courses. This is done through a platform that facilitates hosting all the courses, which are taught in classrooms from Class 9 till post-graduation and can be accessed by anyone, anywhere, at any time. All courses are interactive and are available free of cost to any learner. More than 1,000 specially chosen faculty and teachers from across the country have participated in preparing these courses. The courses hosted on SWAYAM are in four quadrants: (1) video lecture, (2) specially prepared reading material that can be 
downloaded/printed, (3) self-assessment tests through tests and quizzes, and (4) an online discussion forum for clearing doubts.

In order to ensure quality of the content produced and delivered, nine National Coordinators have been appointed. ("About SWAYAM," n.d.).

\section{Literature Review: The Impact of COVID-19 Pandemic in General}

Various research has been conducted studying the impact of the pandemic. Haig et al. (2020) presented an analysis on how COVID-19 has fundamentally changed major global trendlines out to 2050. They conducted research through the analytic framework of the Seven Revolutions initiative, a macrotrends assessment that is continually updated with a 30 -year time horizon. The seven revolutions taken were Population, Resources, Technology, Information, Economics, Security, and Governance. Their research explains the immediate and long-term impact of COVID-19 on various indicators for the above-mentioned revolutions.

Major immediate impacts identified for the population were the elderly being highly vulnerable to disease, the rapid adoption of remote work, migrant labour shortages, and broad border, travel, and immigration restrictions. Their research also states that COVID-19 is likely to accelerate the adoption of robotics, among other forms of automation. According to the study, COVID-19 is highly disruptive in the near term and highly unpredictable in the medium to long terms across every macrotrend area. Those governments, businesses, institutions, and individuals that are most disciplined, rigorous, and honest in their assessment of the challenges being faced will emerge stronger from this crisis.

Rakshit and Paul (2020) highlight the impact of COVID-19 on various sectors such as agriculture, tourism, healthcare, etc., suggesting that during this current pandemic scenario, every enterprise should brace for the uncertainties and challenges that are cropping up. 
Ramankumar (2020) presents an analysis of the economic impact of the COVID-19 pandemic in India.

The Danish Institute for International Studies (2020) explores the implications of COVID-19 for women's health and rights, for refugees, migrants, and IDPs (Internally Displaced Persons), and for food insecurity. This research also discussed selected innovations that have been introduced or implemented in attempts to mitigate the effects of the pandemic.

Seibel et al. (2021) analysed the impact of the pandemic under the perspective of consumer behaviour and the demand for connection and affection from the isolation caused by the pandemic.

Kusumahadi and Permana (2021) studied the impact of COVID-19 on stock return volatility in 15 countries worldwide. Data from January 2019 to June 2020 was analysed to find that changes in exchange rates have negatively affected stock returns in most countries.

\section{Literature Review : The Impact of COVID-19 on Education}

Rowley (2020) discussed the impact of pandemic on higher education. According to him, "Global events like the Great Depression and World War II led to significant societal and cultural changes. This global pandemic will have the same impact. Higher education will not be the same in the future." He discussed various aspects of educational institutions in this changed environment such as financial viability, mission, academic programs, program delivery, technology, and library and student services. Some key findings are: 1) IT experts will now be at the forefront of assisting institutions to offer their academic programs by using technology, and 2) the demands for a library's print collection, one-on-one assistance from the staff, and research in the building itself are likely to be severely curtailed.

Chaddha (2020) discusses the challenges faced by education in coronavirus times as well as strategies to mitigate them, based on UNESCO recommendations. Chaddha states that 
that the pandemic has actually been working as a catalyst for educational institutions to innovate and jump on the digital bandwagon as never before, for their own survival.

Kundu et al. (2020) highlight various issues associated with school closure due to the COVID-19 pandemic which need immediate attention. Some of the mentioned issues are the digital divide and learning inequality that is reinforced by online education, the disproportionate impact of school closures on marginalised children, disruption in school meal services affecting children's nutrition, and an increase in out-of-school children (OOSC).

(Esteban M. Aucejo et al., 2020) describe existing interventions and also suggest policy measures needed to restore school education in pandemic days. A survey of 1500 students at one of the largest public institutions in the United States was done. Results reveal negative effects across many dimensions, such as: $13 \%$ of students have delayed graduation, $40 \%$ have lost a job, internship, or job offer, and 29\% expect to earn less at age 35 . Moreover, these effects were found to be highly heterogeneous. The researchers also found that lower-income students are more likely to be negatively impacted compared to their higher-income counterparts. Hence, Aucejo et al states that by focusing on addressing the economic and health burden imposed by COVID-19, policy makers may be able to prevent COVID-19 from widening existing achievement gaps in higher education.

Mohapatra (2020) lays down few suggested solutions for addressing the issues of technical gap, digital divide, and network problems, solutions that will further strengthen the online education system of India. The author says, "Policymakers need to provide free Wi-Fi to millions of villages; which is far more important than the providing free Wi-Fi at the airports. The foundation of one lakh smart villages can be laid at the cost of 100 smart cities." Yasmin et al. (2020) explains different types of stress relevant in the life of a student, mainly due to the pandemic, and how this stress can impact learning. According to the study, 
expanding the role of faculty advisors/counsellors, improved orientation for new graduate students, and more flexibility in core requirements can help in alleviating distress.

Rajhans et al. (2020) designed a survey to find changes in optometry training and the adaptations of Indian optometry educators during the COVID-19 pandemic. In their opinion, the pandemic is proving to be a constructive disruptor, giving an opportunity for restructuring the present conventional classroom-based education system. The rapid transition to online education proved to be beneficial for optometry students, and has also created momentum for continued education for practicing optometrists in the country.

Shetty et al. (2020) assessed the attitude of students towards online learning in the subject of ENT. Results of their study reveal that students favoured online learning for sustaining their academic interest and educational development during this pandemic.

Ramos (2020) discusses the impact of technology on education and also on changing workforce requirements when he states, "The education system that gets the best results for everyone likely will feature a much greater emphasis on middle and high school career training and a hybrid approach to in-person classroom and distance learning." The article predicts that virtual learning will stay — at least in some capacity.

(Michael A. Cusumano, 2013) focuses on the economic implications as educational institutions expand online learning initiatives. The author has critically examined the ongoing trend of "free" online education. He states, "Economists and management researchers see prices as important signals of value. Prices may signal other things, such as status and cost. But if we agree they have something to do with value, then 'free' sends a signal to the world that what you are offering may not be worth paying for." The impact on second- and thirdtier universities and colleges, as well as community colleges, which play important roles for education and economic development in their local regions and communities, is discussed. 
(Fangmei Li et al., n.d.) describes about the campaign launched by the Chinese government during pandemic that created a large-scale online education. They analysed the impact of this large-scale online education activities on society and education. This study highlights certain drawbacks of online learning from a student's point of view, like lack of self-control and self-learning ability and the absence of face-to-face teachers or even parental supervision.

To summarize, the literature survey states that online learning played an important role in continuing education during COVID-19. Various surveys conducted indicate that online delivery was perceived as effective by learners from different fields of study, even though some drawbacks of online delivery were observed.

\section{A Perspective on Online Education}

The role of education is to help an individual realise his full potential and become a responsible citizen of society. As a responsible citizen, an individual should be able to contribute to the overall development of their society and the welfare of fellow human beings. Getting a job, doing a profession, starting a business, and creating wealth are all subcomponents of this larger objective of education.

COVID-19 has inadvertently positively impacted the spread of online education This has opened up a number of possibilities for the delivery of online education and associated service industries. Experimentation in online education has been extensive. Generally, individuals who have been hesitant to try online delivery have been forced to do it because of the prolonged lockdown and restricted mobility of teachers and students. For several months, educational institutions were closed. All these accelerated the experimentation of online delivery of education.

General benefits of online delivery of education include spread and volume. By spread, we mean the ability to reach a large number of recipients irrespective of their 
geographical location. Because the spread is vast, the volume or the number of recipients who can gain from an individual learning resource online is also significantly higher. As a consequence of the spread and volume access to education has become universal. It doesn't matter where a person is located, or what is their socioeconomic status is; he can still access quality education at his will.

It is economically feasible for the learner to learn from the best of the faculty in the world for a small fee or for free. Therefore, the price of the education is not a barrier. From the point of the academic resource persons, it is economically viable for him or the institution since large number of recipients register for the courses, and even a modest fee will lead to break-even volume.

There is significant amount of flexibility in learning on dimensions related to topics, sequencing, time invested on learning, the pace at which the learning happens, what is to be learned, and how deep the learning should be. All these options are left to the learner and he can tailor the learning opportunities to his needs and requirements.

There is an option to seek certification. It is not necessary that every learner should end up with a certification, the exception being those who have enrolled in formal institutions (where the physical delivery is converted to online delivery). Since the certification is optional and the learning can be customised to the individual's priorities. The learning community is potentially larger than student community registered in institutions . The new community of learners include members from other strata of the society as well that has emerged as a consequence of the spread of online education. It is important to emphasize that learning is not necessarily now restricted to individuals who are learning in the traditional learning systems like schools, universities, colleges, polytechnics and other places for employment. Learners here means adults who want to learn, even senior citizens who want to learn something which they could not do when they were younger. There is a real possibility 
for the general public to study things they did not have the chance to explore before. And therefore, there is a new community of learners irrespective of age, sex, creed, and economic strata who would like to learn from the online delivery mode of education.

Due to the pandemic, which lasted for about 24 months, the experience of online education has made people believe that online education is a real possibility, and this is likely to stay.

The composition (the mix of online and offline education) and spread of education may vary, but a significant component of the education delivery process is likely to be online driven (based on economics of delivery and convenience).

Technological advancements, new applications (both computer-based/web-enabled and mobile based applications), and new platforms for delivering content, academic support, and service providers may emerge and experience significant growth. These things are also likely to consolidate as time passes. There are no specific standards related to ICT-enabled education delivery in this industry as of now.

The interaction between the learner and the resource provider may become better and better as advancements in ICT applications are deployed.

Customised learning for any learner could become a reality. This means that learners will tend to learn at their own pace and be able to choose specific topics that interest them rather than doing an entire course.

Because the market is exploding and there is an opportunity for everybody to participate, a wide range of learning material would be available on any topic.

\section{Unintended Consequences of Online Education}

\section{Universalisation of Education}

According to the National Education Policy (2020), "Providing universal access to quality education is the key to India's continued ascent." The policy is aimed at "achieving an 
equitable and inclusive education system by 2030." As digitisation improves access to learning material, it would expand. This has the potential to contribute towards realising the NEP 2020 goal in the near future. Given education's high demand and increased supply, it is a non-regimented market opportunity that can further accelerate the realisation of NEP. People from different socioeconomic backgrounds can now access education at their own pace and comfort. In some sense what a 'Right to Education' cannot achieve, disruption in education by COVID-19 has created: online delivery as an option to accomplish universal access to education

\section{Role of Knowledge Creators}

With the advent of Online learning, Knowledge creators/educators are emerging as individual brands. They can reach any learner anywhere at any time by using technology. Educational institutions will lose their monopoly and ownership on faculty. Academics would become an institution by themselves in the near future. Universities can be seen as a federation of distinguished academics in their respective areas.

\section{Learning Transcends Socioeconomic Barriers}

E-learning platforms break the shackles of distance, age, gender, and other socioeconomic inhibitions. For example, in a country like India where the majority of the population resides in rural areas, online learning platforms and digitization can bring the best of teachers to any motivated learner. These platforms create a conducive environment for learners irrespective of their age and social and economic backgrounds. Online education delivery systems provide elderly or underprivileged women with learning aptitude, an opportunity to learn without any social inhibitions.

\section{Brick-and-mortar Universities}

Consequent to the popular acceptance of online education, we have a situation where teachers can easily reach their learners and the learners can pick and choose their resource 
providers without the advice or control of the university. This opens up an uncontrolled marketplace which will eventually stabilise based on the quality of what is being offered. Several segmentations within the market would emerge. The situation will turn into positive chaos. The brick-and-mortar universities need to address the challenge arising out of this. In some sense their existence may be challenged. They need to do something different and relevant to continue to stay in business. They will have to focus on the creation of new knowledge, applied research, and experiment-based research.

\section{Learning Management Systems}

With the growing trend of online learning, learning management systems (LMS), which track a particular course from advertising to registration, course attendance, participation monitoring, examination, evaluation, class performance and final certification, will emerge as critical. An LMS provides support from enrollment to certification. The demand for new features and designs for LMS will continue to grow.

\section{Academic/Teaching Assistance}

While a course is delivered by a subject matter expert, in order to provide support for learners to assimilate their learning, we need to create an academic support system which will facilitate the learners to learn at their own pace. Depending on the class size, we need to employ a number of academic associates who will work with the cohorts to facilitate their learning process. They will answer questions, send emails on behalf of the resource provider, and bring a sense of comfort and engagement to the learners. This is a huge opportunity. For example, if the resource provider is global, and if they are running a class for approximately 5000 students, there may be a need for up to 25 academic associates who can work with smaller groups of 20 learners each. This would be a huge academic employment opportunity.

\section{Opportunities for IT Companies}


IT companies would be encouraged to come up with better products, better interfaces, better graphics, and better ways of presenting conferences, seminars, etc. They will want to launch mobile applications where the learning experience can be enhanced. Conducting exams could be a challenge for resource providers, and they may need tools which will help with remote proctoring. Some security features like candidate identification, proctoring the exam are necessary. This is an opportunity for developing several hi-tech information technologies related products in this area.

The impact of online delivery of education has to be seen from the perspective of learners, the teaching resources, the subject matter, the supporting institutions, and the ICT technology infrastructure. Combining these things appropriately will create a new ecosystem for learning opportunities. This will also result in a marketplace where the academic institutions would become somewhat of a market regulator. The detailed description of this is not attempted here.

Efficiencies are evident from the learners as well as the resource provider point of view because there is no need for time synchronisation between the learner and the resource person. The learner can learn at his own pace. Economies of scale are in favour of the resource provider. Therefore, efficiency of the system is obvious.

Effectiveness can be considered as a challenge but in our opinion, effectiveness is also accomplished because the online delivery of education system provides an opportunity for the learners to be self-paced and to learn what they want to learn. In some sense, each individual will reach what is their optimal learning potential. That optimal potential will be decided by the learner himself, in terms of the depth and coverage of the topic that he wants to learn, the pace at which he wants to learn, and whether he would like to have a certification or not. An individual can learn for enjoyment or for employability skills. Since all these options are left to the learners, there is a significant amount of effectiveness that gets into the system. To 
ensure that the learners are engaged, it is not a good idea to have recorded lessons delivered through the online platform. The lessons should be delivered in real time so that there is engagement between the learner and the resource provider.

The learning process can be divided into multiple segments, viz., skill, concept, perceptions, experience, and experiment-based learning.

If we consider these as five different segments of learning, and we put them on an $\mathrm{x}$ axis, and effectiveness of online delivery in terms of achieving learning goals on the $y$-axis, we can see that at the skills level, the effectiveness of online learning would be very high. However, with experiment based learning, it will be very low.

\section{Figure 3}

\section{Effectiveness of Online Education Delivery}

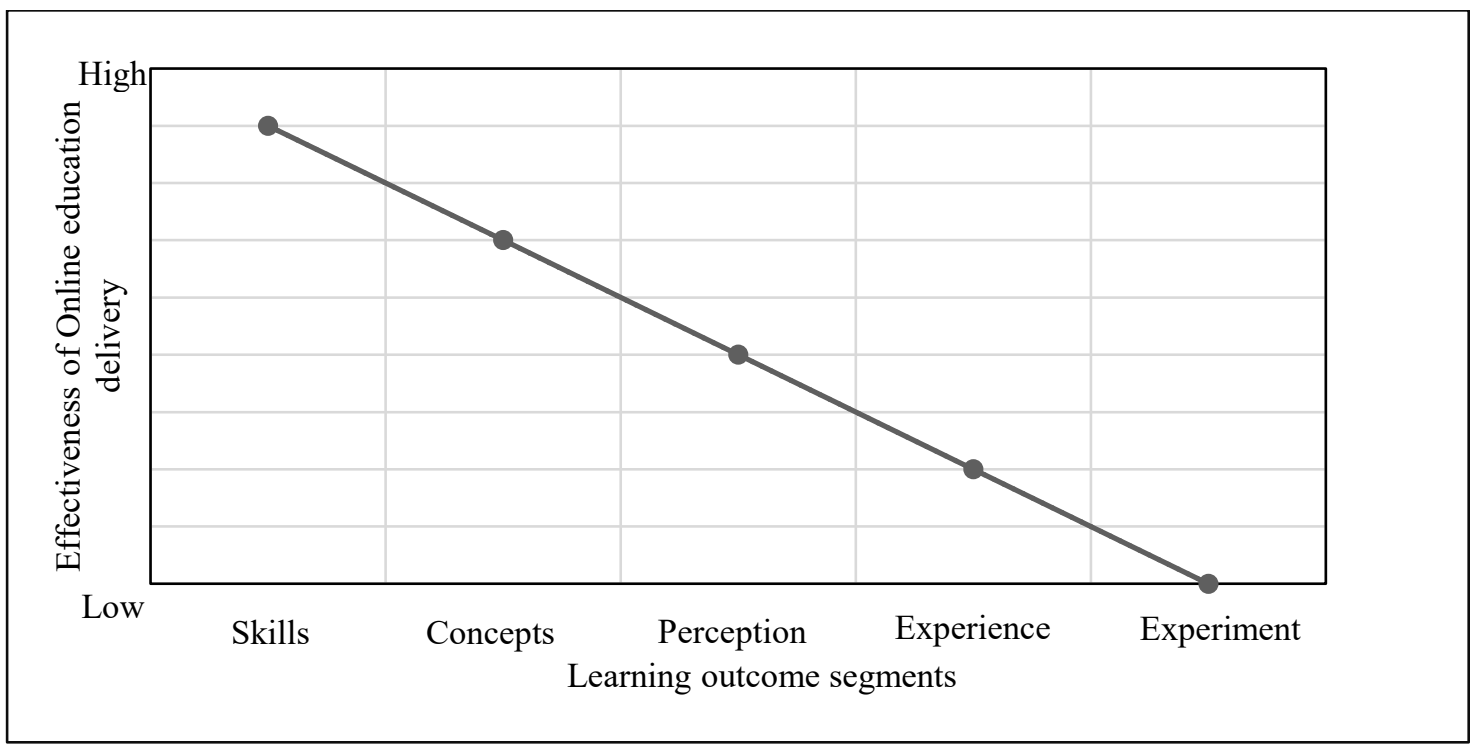

The idea here is that skill-based learning, irrespective of the subject and grade, can be effectively done by online delivery, whereas experiment based learning would be difficult to deliver though the online mode.

Experiment based learnings may have some difficulties and would also require significant investments of scientific infrastructure to support it. Therefore, a broad observation is that the higher the investment on the learning infrastructure, the lesser the 
chances that particular learning process can be delivered through the online mode. This is not an absolute statement. This is likely to change in the near future.

Discussion within an online delivery mode is not easy, but can be accomplished with social groups and a community of learners. Learning by doing may be difficult by online mode, more specifically in fields like medical, biological, and diagnostic services, although simulation to can help in the learning process in such contexts to a large extent. In an online delivery mode, peer learning is indirect. It can happen only through community participation.

In an online delivery mode, control and monitoring of the student's participation, engagement and attentiveness is difficult. Therefore, it is necessary for students to have selfdiscipline to learn something through an online mode.

Regular attendance in classes and discipline should be self-driven. This would be the biggest weak point because adolescents may not be able to practice self-discipline and therefore, they may fall out from the learning process.

The need for support systems in terms of information technology as well as academic associates is an important element of this learning process.

Knowledge coupled with information technology and innovation in delivery would be the key for impactful online delivery of programs.

Institutions would become a federation of knowledge workers plus information technology. Only those institutions which are able to innovate and adopt technology rapidly will be able to survive and rest will fade away.

Educational institutions which are in the business of imparting craftsmanship would survive the onslaught of online delivery of education. Even though a significant portion of the craftmanship can be converted to online delivery mode. 


\section{Conclusion}

The COVID-19 pandemic has disrupted education, but the adoption of online education has been a positive effect of this situation.

Online delivery of education across different segments and different disciplines is here to stay. The composition and mixture of online education with physical delivery can vary.

The delivery of institutionalised education would go through a dramatic change due to the adoption of and the experience with online delivery during this pandemic time.

Online delivery of education and its acceptance would take India a step closer to the National Education Policy. Universal access to education at all levels is a reality, thanks to the adoption of online delivery. The adoption of online delivery of education opens the potential for new IT products and innovations in the learning process.

Mass customisation (i.e., customising the learning objectives, learning goals, and learning points to individual customers) is a reality.

The emergence and application of technology to the education delivery process is a positive cycle. This positive cycle will become a virtuous cycle. This will result in better opportunities for learners. The future of online delivery is exciting. It will emerge as an alternative model for brick-and-mortar universities. This mode would enable learning to become an exciting process for the general public. It will take education beyond the formal institutions. It will open up communities to learn at their own pace. 


\section{References}

88\% of all COVID-19 deaths in India in age group of 45 years and above: Government (2021, March 24). Times of India. https://timesofindia.indiatimes.com/india/88-ofall-covid-19-deaths-in-india-in-age-group-of-45-years-and-abovegovernment/articleshow/81672749.cms

About SWAYAM. (n.d.). Swayam Central. Retrieved September 26, 2021, from https://swayam.gov.in/about

About Us. (n.d.). Khan Academy. Retrieved September 26, 2021, from https://www.khanacademy.org/about

Aucejo, E., French, J., Araya, M. P., \& Zafar, B. (2020). The impact of COVID-19 on student experiences and expectations: Evidence from a survey. National Bureau of Economic Research. https://doi.org/10.3386/w27392

Bharathi, D., \& Dinesh, G. (2021). Impact of COVID-19 pandemic on Indian services sector. SSRN Electronic Journal, 10-11. https://doi.org/10.2139/ssrn.3885430

BS Web Team. (2020, November 28). India's GDP Q2 2020: Economic contraction narrows to $7.5 \%$ from $23.9 \%$ in Q1. Business Insider. https://www.business$\underline{\text { standard.com/article/economy-policy/india-s-gdp-q2-2020-economic-contraction- }}$ narrows-to-7-5-from-23-9-in-q1-120112700855_1.html

Coronavirus (COVID-19) vaccinations. (n.d.). Our World in Data, https://ourworldindata.org/covid-vaccinations (retrieved: 2021, September 27)

Coronavirus in India: Latest Map and Case Count https://www.covid19india.org (retrieved: 2021, September 26)

COVID-19 and education in emergencies. (2020, March 30). Education Cannot Wait. https:/www.educationcannotwait.org/covid-19/ 
COVID-19: Another reason why unlock 1.0 may be ill-timed in India. (2020, June 9). India Today. https://www.indiatoday.in/news-analysis/story/covid-19-unlock-1-0-indialockdown-coronavirus-cases-1687162-2020-06-09

Cusumano, M. A. (2013). Are the costs of 'free' too high in online education?

Communications of the ACM, 56(4), $26-28$.

https://doi.org/10.1145/2436256.2436264

Fangmei Li, Shanshan Wu, \& Ming Zhou. (2020). School's Out, But Class's On”, The

Largest Online Education in the World Today: Taking China's Practical Exploration

During The COVID-19 Epidemic Prevention and Control as An Example. Best Evid Chin Edu 2020, 4, 501-519.

http://dx.doi.org/10.2139/ssrn.3555520Haig, C. S., Ahmed, H., Newton, H., \& Brannen, S. (2020). COVID-19 reshapes the future. The Center for Strategic and International Studies. https://www.csis.org/analysis/covid-19-reshapes-future

Kumar, P. (2021, May 1). India sees over 4 lakh Covid cases in a day in new global record.

NDTV. https://www.ndtv.com/india-news/coronavirus-over-4-lakh-covid-19-cases-

$\underline{\text { 3-523-deaths-in-india-in-biggest-spike-in-24-hours-2425716 }}$

Kusumahadi, T. A., \& Permana, F. C. (2021). Impact of COVID-19 on global stock market volatility. Journal of Economic Integration, 36(1), 20-45.

https://doi.org/10.11130/jei.2021.36.1.20

Mohapatra, A. K. (2020). Editorial: Impact of Covid-19 on Higher Education. Journal of Management \& Public Policy, 11(2), 4-6.

Novel coronavirus (COVID-19) cases data. (2020, February 7). OCHA. Retrieved September 26, 2021, from https://data.humdata.org/dataset/novel-coronavirus-2019$\underline{\text { ncov-cases\# }}$ 
Rajhans, V., Memon, U., Patil, V., \& Goyal, A. (2020). Impact of COVID-19 on academic activities and way forward in Indian optometry. Journal of optometry, 13(4), 216226. https://doi.org/10.1016/j.optom.2020.06.002

Rakesh S., Kriti K., and Oommen C. K. (2021, June 3). India's vaccine rollout: A reality check. ORF. https://www.orfonline.org/research/indias-vaccine-rollout-a-realitycheck/

Rakshit, D., \& Paul, A. (2020). Impact of COVID-19 on sectors of Indian economy and business survival strategies. International Journal of Engineering and Management Research, 10(03), 51-55. https://doi.org/10.31033/ijemr.10.3.8

Ramos, R. (n.d.). Rethinking Education for Changing Times. USA Today, (2020).

Rowley, W. J. (2020). Higher education in the midst of a pandemic: A dean's perspective. International Dialogues on Education Journal, 7(1/2).

Seibel, S., Santos, I.H., and Silveira, I. (2021). Covid-19's Impact on Society, Fashion Trends and Consumption. Strategic Design Research Journal, 14, 92-101.

Shetty, S., Shilpa, C., Dey, D., \& Kavya, S. (2020). Academic crisis during COVID 19: Online classes, a Panacea for imminent doctors. Indian Journal of Otolaryngology and Head \& Neck Surgery. https://doi.org/10.1007/s12070-020-02224-x

Shinde, L., Sehgal, S., Madheswaran, G., Mukherjee, P., Verkicharla, P., Easwaran, S., \& Bandamwar, K. (2021). Impact of COVID-19 on Indian optometrists: A student, educator, and practitioner's perspective. Indian Journal of Ophthalmology, 69(4), 958. https://doi.org/10.4103/ijo.ijo_3386_20

John, T. J., and Seshadri, M.S. (2020, September 29). Imperatives after India's September virus peak. The Hindu. https://www.thehindu.com/opinion/lead/imperatives-afterindias-september-virus-peak/article32719000.ece 
Transformation through education. (n.d.). edX. Retrieved September 26, 2021, from https://www.edx.org/about-us

Statista Research Department. (2021, May 10). Topic: Coronavirus (COVID-19) in India. https://www.statista.com/topics/6135/coronavirus-covid-19-outbreak-in-india/ UN Women. (2020, September 16). COVID-19 and its economic toll on women: The story behind the numbers. https://www.unwomen.org/en/news/stories/2020/9/featurecovid-19-economic-impacts-on-women

WHO Coronavirus (COVID-19) Dashboard. (n.d.).

https://covid19.who.int/info/ (retrieved: 2021, September 26) 


\section{Appendix}

\section{List of Abbreviations used in the paper}

\begin{tabular}{|c|c|}
\hline Abbreviations & Full form \\
\hline AICTE & All India Council for Technical Education \\
\hline CAT & Common Admission Test \\
\hline CBSE & Central Board of secondary Education \\
\hline CMI & Chennai Mathematical Institute \\
\hline COVID-19 & Coronavirus disease 2019 \\
\hline CTE & Career and Technical Education \\
\hline DVD & Digital versatile disc \\
\hline E-classes & electronic education \\
\hline E-education & electronic education \\
\hline e-learning & electronic learning \\
\hline ENT & Ear, nose and throat \\
\hline GLIM & Great Lakes Institute of Management \\
\hline IAS & Indian Administrative Service \\
\hline ICSE & Indian Certificate of Secondary Education \\
\hline IDPs & Internally displaced persons \\
\hline IGNOU & Indira Gandhi National Open University \\
\hline IIT & Indian Institute of Technology \\
\hline IMSc & Institute of Mathematical Sciences, Chennai \\
\hline Inc & Incorporated \\
\hline IT & Information Technology \\
\hline JEE & Joint Entrance Examination \\
\hline MOOC & Massive Open online course \\
\hline NCERT & National Council of Educational Research and Training \\
\hline NEET & National Eligibility Entrance Test \\
\hline NITTR & National institute of Technical Teachers Training and Research \\
\hline NPTEL & National Programme on Technology Enhanced Learning \\
\hline
\end{tabular}


The Future of Online Learning

\begin{tabular}{|l|l|}
\hline SMS & Short message service \\
\hline SPOC & Single point of contact \\
\hline SRM & Sri Ramaswamy Memorial \\
\hline UGC & University Grants Commission \\
\hline UNESCO & $\begin{array}{l}\text { The United Nations Educational, Scientific and Cultural } \\
\text { organization. }\end{array}$ \\
\hline UNICEF & United Nation's International Children's Emergency Fund \\
\hline WHO & World Health Organisation \\
\hline Wi-Fi & Wireless Fidelity \\
\hline
\end{tabular}




\section{COVID-19 in India - Milestones}

\begin{tabular}{|c|c|c|}
\hline S.no & Date & Major Events \\
\hline 1. & 30 Jan 2020 & First confirmed case \\
\hline 2. & 01 Feb 2020 & First airlift from Wuhan, China \\
\hline 3. & 12 Mar 2020 & First confirmed death \\
\hline 4. & 15 Mar 2020 & 100 confirmed cases \\
\hline 5. & 22 Mar 2020 & One day Janta Curfew and passenger air travel suspended \\
\hline 6. & 25 Mar 2020 & Nationwide Lockdown \\
\hline 7. & 05 Apr 2020 & 100 confirmed deaths \\
\hline 8. & 14 Apr 2020 & 10,000 confirmed cases, lockdown extended till $3^{\text {rd }}$ May \\
\hline 9. & 01 May 2020 & Nationwide lockdown further extended till 17 May \\
\hline 10. & 17 May 2020 & Nationwide lockdown further extended till 31 May \\
\hline 11. & 31 May 2020 & 5,000 confirmed deaths \\
\hline 12. & 25 May 2020 & $\begin{array}{l}\text { Domestic flight services resume in a calibrated manner, with only } \\
30 \% \text { of regular schedules. }\end{array}$ \\
\hline 13. & 01 Jun 2020 & Lockdown 5.0 till June 8 \\
\hline 14. & 08 Jun 2020 & Phased reopening begins with Unlock 1.0 \\
\hline 15. & 12 Jun 2020 & India overtakes UK to become 4 th worst coronavirus-hit country \\
\hline 16. & $01 \mathrm{Jul} 2020$ & Unlock 2.0 guidelines come into force \\
\hline 17. & $06 \mathrm{Jul} 2020$ & India becomes third worst coronavirus-hit country. \\
\hline 18. & 15 Jul 2020 & Phase- 1 clinical trials Covaxin starts across the country. \\
\hline 19. & 01 Aug 2020 & Phase 3.0 of Unlock comes into force \\
\hline 20. & 26 Aug 2020 & Serum Institute of India starts India trials of Covishield \\
\hline 21. & 21 Sep 2020 & Schools partially reopened in several states \\
\hline 22. & 27 Sep 2020 & $\begin{array}{l}\text { Covid-19 tally goes past } 60 \text { lakhs, with total recoveries crossing } \\
\text { the } 50 \text {-lakh milestone. }\end{array}$ \\
\hline 23. & 30 Sep 2020 & Unlock 5.0 guidelines issued \\
\hline 24. & 19 Dec 2020 & $\begin{array}{l}\text { Covid-19 tally cross } 1 \text { crore-mark } \\
\text { And New variant strain detected in UK }\end{array}$ \\
\hline 25. & 16 Jan 2021 & India begins coronavirus vaccination programmes. \\
\hline 26. & 19 Feb 2021 & India completes one crore vaccinations in 34 days \\
\hline
\end{tabular}




\begin{tabular}{|c|c|c|}
\hline 27. & 23 Feb 2021 & $\begin{array}{l}\text { Two new strains of Covid-19 detected in India, } \\
187 \text { people tested positive for the UK strain, } \\
6 \text { people detected with the South African strain, } \\
1 \text { with Brazilian strain }\end{array}$ \\
\hline 28. & 01 Mar 2021 & $\begin{array}{l}\text { Second phase (above the age of } 60 \text { and those between } 45 \text { and } 59 \\
\text { with specific comorbidities) of vaccination drive begins. }\end{array}$ \\
\hline 29. & 22 Mar 2021 & $\begin{array}{l}\text { India reports } 46,951 \text { cases in a single day — the highest spike } \\
\text { since November. }\end{array}$ \\
\hline 30. & 01 Apr 2021 & $\begin{array}{l}\text { Vaccinations were made available to all Indians over the age of } \\
45 .\end{array}$ \\
\hline 31. & 11 Apr 2021 & $\begin{array}{l}\text { Export of the Antiviral drug Remdesivir banned due to } \\
\text { skyrocketing demand }\end{array}$ \\
\hline 32. & 14 Apr 2021 & India recorded more than 200,000 new daily cases \\
\hline 33. & 28 Apr 2021 & $\begin{array}{l}\text { United States president Joe Biden pledged to deliver US\$100 } \\
\text { million worth of supplies to India, including oxygen cylinders, } \\
\text { concentrators, and generation units, personal protective } \\
\text { equipment (including masks), vaccine ingredients, and COVID } \\
\text { tests }\end{array}$ \\
\hline 34. & 01 May 2021 & $\begin{array}{l}\text { India officially expanded vaccination drive to all adults over the } \\
\text { age of } 18 \\
\text { Seven regions experienced vaccine shortage }\end{array}$ \\
\hline 35. & 09 May 2021 & $\begin{array}{l}\text { India reported } 403,405 \text { new confirmed cases with } 4^{\text {th }} \text { day in a row } \\
\text { with above } 4 \text { lakhs. }\end{array}$ \\
\hline 36. & 11 May 2021 & $\begin{array}{l}\text { India reported } 329,942 \text { new confirmed cases, the lowest number } \\
\text { of since } 26 \text { April }\end{array}$ \\
\hline 37. & 26 May 2021 & India surpassed 27 million total cases \\
\hline 38. & 04 Oct 2021 & $\begin{array}{l}\text { Health ministry started drone delivery of Covid vaccines in } \\
\text { remote areas. }\end{array}$ \\
\hline 39. & 21 Oct 2021 & Cumulative vaccination coverage crossed the 100 -crore mark. \\
\hline
\end{tabular}

